\title{
Antibacterial Activity of Microalgae Dunaliella salina, Tetraselmis chuii and Isochrysis galbana Against Aquatic Pathogens
}

\author{
Ita Widowati ${ }^{*}$, Muhammad Zainuri², Hermin Pancasakti Kusumaningrum³ ${ }^{3}$, Yann Hardivillier ${ }^{4}$ \\ ${ }^{1}$ Department of Marine Sciences, Faculty of Fisheries and Marine Sciences, Diponegoro University \\ ${ }^{1}$ Department of Oceanography, Faculty of Fisheries and Marine Science, Diponegoro University \\ ${ }^{3}$ Department of Biology, Faculty of Sciences and Mathematics, Diponegoro University \\ Jl. Prof Soedarto, SH, Tembalang, Semarang -50275, Indonesia \\ ${ }^{4}$ Laboratoire du MMS, Le Mans Université \\ Av. Olivier Messiaen, 72085 Le Mans, France \\ Email: itawidowati@lecturer.undip.ac.id
}

\begin{abstract}
Recently, expanded consideration has been paid to the business and potentiality of microalgae. Some microalgae are at present being studied for their capacity to find important metabolites for the drug industry or aquacultural applications. Concerning these biotechnological challenges, there is a consistent exertion accommodated in both finding and taking advantage of new microalgal assets and fostering their putative business results or modern valorizations. The crude methanol extracts of three microalgae, Dunaliella salina, Tetraselmis chuii, and Isochrysis galbana, have been investigated for antibacterial activity using the disk diffusion method against aquatic pathogens of fish, shrimp, and shellfish e.g. Pseudomonas fluorescence and Vibrio harveyi. This research aimed to analyze the antibacterial activity of crude extract of these microalgae against aquatic pathogens. The disk diffusion method was used to investigate the antibacterial activity. The result showed that only $T$. chuii has the inhibition zone for both tested bacteria $P$. fluorescence and V. harveyi with the inhibition zone of $3.0 \pm 0.6 \mathrm{~mm}$ on $100 \mu \mathrm{g}$. $\mathrm{g}^{-1}$ of extract concentration and $4.20 \pm 1.1 \mathrm{~mm}$ against $P$. fluorescence on $10000 \mu \mathrm{g}$. $\mathrm{g}^{-1}$ of extract concentration. While $D$. salina and I. galbana have inhibition zone only for $V$. harveyi with the inhibition zone of $4.4 \pm 0.6 \mathrm{~mm}$ and $3.2 \pm 0.7$ $\mathrm{mm}$ on $10000 \mu \mathrm{g}$. g-1 of extract concentration. These three microalgae may have potential use in aquatic pathogens as antimicrobial agents. It would be possible to develop biologically active compounds of microalgae as a functional feed for aquaculture.
\end{abstract}

Keywords: antibacterial activity, aquatic pathogens, marine microalgae, microalgal extract.

\section{Introduction}

The problems of microbial resistance in aquaculture have led to a search for new antimicrobial compounds. The significant issues of current antimicrobial agents are harmfulness, absence of adequacy, restraining cost, and their frequent use leading to the emergence of resistant strains. Subsequently, there is an earnest need to look for elective biodegradable agents, which should be free from side effects. It is generally that natural compounds are biodegradable and eco-friendly. Microalgae are mainly utilized in aquaculture particularly due to their nutrition contents (Khatoon et al., 2014; Hoai Thu et al., 2015). Besides nutrition advantages, microalgae also have been explored for the use of pigments and other biological purposes. Different species of microalgae are known as a fundamental food source in the rearing of all stages of marine bivalve mollusks (clams, oysters, and scallops), and of the post-larval stages of some marine gastropods (e.g. abalone), larvae of marine fish, penaeid shrimp, and zooplankton. There are three distinct types of live feed, usually utilized in commercial larvae culture of fish and shellfish: 1 ). Different species of microalgae ranging between 2 $\mu \mathrm{m}$ and $20 \mu \mathrm{m}$ in size for bivalves, penaeid shrimps, rotifers, copepods, and fish; 2). The rotifers Brachionus plicatilis and B. rotundiformis (50 to 200 $\mu \mathrm{m})$ in size for crustaceans and marine fish; 3) The brine shrimp Artemia sp. nauplii (400 to $800 \mu \mathrm{m}$ ) in size for crustaceans and fish (Lavens and Sorgeloos, 1996).

The bioactive compound also can be found in macroalgae such as Sargassum sp. (antibacterial, antiviral, antioxidants) (Hardouin et al., 2013; Widowati et al., 2014; Susilowati et al., 2015). However, the application of macroalgae for aquaculture is being limited, for example, it cannot be used as feed for larval stages. Microalgae have rich sources of structurally and biologically active metabolites including antioxidants (Widowati et al., 2017) and antibiotics which inhibit bacteria responsible for fish, shellfish, and human pathogens (Pradhan et al., 2011; Najdenski et al., 2013). 
Secondary or primary metabolites produced by these microorganisms may be potential bioactive compounds of interest in aquafeed as an antimicrobial agent (Pradhan et al., 2011). Therefore, some microalgae have been suggested as a new functional feed ingredient (Becker, 2004). This research aimed to determine the antibacterial activity of three species microalgae Dunaliella salina (Teodoresco, 1905), Tetraselmis chuii (Butcher, 1959), and Isochrysis galbana against aquatic pathogens Pseudomonas fluorescence (Flügge, 1886) and Vibrio harveyi (Johnson and Shunk, 1936; Baumann et al., 1981).

\section{Materials and Methods}

\section{Culture of microalgae}

Three species of microalgae Dunaliella salina, Tetraselmis chuii, and Isochrysis galbana were cultured by using batch continuous culture with the comparison between algae and seawater was 1 : $3 \mathrm{~L}$. Walne was used for the nutritional compound for the culture compared by volume of culture $1 \mathrm{~mL}: 1 \mathrm{~L}$ with luminous intensity 1500 lux to 3000 lux and 23 to 25 ${ }^{\circ} \mathrm{C}$ for temperature (Harrison and Berges, 2005).

The density of the culture microalgae was counted with a Neubauer hemocytometer by using a binocular microscope. The density of the microalgae was counted every day. The microalgae were homogenized first before putting the pipet into the hemocytometer and closed with the cover glass. Then, it was observed under a microscope and started to count with the equation (Hadioetomo, 1993):

$$
N=\frac{(N 1+N 2)}{2} \times \frac{1}{10.2 \mathrm{~mm}^{2} \times 0.1 \mathrm{~mm}} \times \frac{1 \mathrm{~mm}^{3}}{10^{-3} \mathrm{~mL}}
$$

Note: $\mathrm{N}=$ Cell density (cell. $\mathrm{mL}^{-1}$ ); $\mathrm{N} 1=$ Total cell in 80 small squares (replica 1 ); N2 = Total cell in 80 small squares (replica 2); $0.2 \mathrm{~mm}=$ Wide of hemocytometer in 80 squares; $0.1 \mathrm{~mm}=$ The depth liquid on a hemocytometer.

The microalgae were harvested on the stationary phase of culture. The biomass of microalgae was obtained with a centrifuge at 5000 rpm (1 rpm equal 1/60 Hz) for $10 \mathrm{~min}$ and then dried in a room at view days, then called dry biomass (Mishra et al., 2012).

\section{Extraction}

Extraction involves the separation of plant or animal tissues from inactive or inert components by using selective solvents in standard extraction procedures. Dry biomass was extracted by using methanol solvent with sonification at $50 \mathrm{~Hz}$ for 15 min. Then, the solvents were evaporated by using rotary evaporation until there is no solvent called with crude extract bioactive of microalgae (Trianto et al., 2011).

\section{Antibacterial activities}

The screening of antibacterial activities from extract microalgae against two aquatic pathogens bacteria Vibrio harveyi and Pseudomonas fluorescence was performed by using the disk diffusion method. The extract of each microalga was diluted into three concentrations Dunaliella salina $13.32 \mu \mathrm{g} . \mathrm{g}^{-1}, 1.33 \mu \mathrm{g} . \mathrm{g}^{-1}$, and $0.13 \mu \mathrm{g}$. $\mathrm{g}^{-1}$; Tetraselmis chuii $12.61 \mu \mathrm{g} . \mathrm{g}^{-1}, 1.26 \mu \mathrm{g}$. $\mathrm{g}^{-1}$, and 0.13

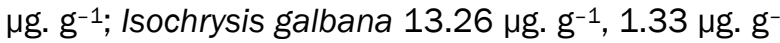
1 , and $0.13 \mu \mathrm{g}$. $\mathrm{g}^{-1}$. One of the $50 \mu \mathrm{L}$ culture of tested bacteria in the logarithmic phase were spread on to agar medium. Several paper disks $(8 \mathrm{~mm}$; Advantec Toyo Roshi, Ltd, Japan) containing $30 \mu \mathrm{L}$ of each concentration were placed on the respective agar surface. The plates were incubated at room temperature for $48 \mathrm{~h}$. Antibacterial activity was defined by inhibition zones around the paper disk (Radjasa et al., 2009).

\section{Results and Discussion}

\section{Culture of microalgae}

Microalgae were counted for the density every day with a hemocytometer under the microscope binocular. The highest densities are found in Dunaliella salina $\left(4.4 \times 10^{6}\right.$ cells. $\left.\mathrm{mL}^{-1}\right)$, followed by Isochrysis galbana $\left(3.2 \times 10^{6}\right.$ cells. $\left.\mathrm{mL}^{-1}\right)$, and the lowest is in Tetraselmis chuii $\left(0.96 \times 10^{6}\right.$ cells. $\left.\mathrm{mL}^{-1}\right)$. However, the highest dry biomass is found in $I$. galbana (3.54 g) and the lowest is in D. salina (1.026 g). The highest density in $D$. salina is not in line with the dry biomass, this may be due to the cell size since $D$. salina cell is $(2.8-40 \mu \mathrm{m}$, Borovkov et.al, 2019) and $I$. galbana cell size is 4-6 $\mu \mathrm{m}$ (Cordoba-Matson, 2013). The cell size could change with growth, light intensity, and different condition (Borowitzka, 2021). The result of the density of microalgae Dunaliella salina, Tetraselmis chuii, and I. galbana is shown in Figure 1.

\section{Extraction}

The microalgae were harvested on the stationary phase of culture. Biomass and crude extract of microalgae are shown in Table 1 and 2. The potential of extract microalgae to produce substances 


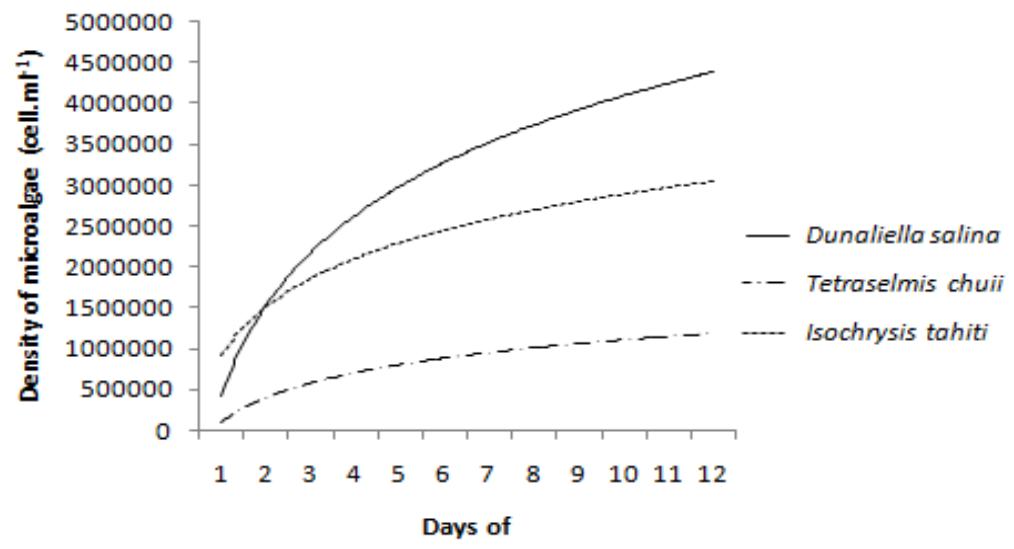

Figure 1. Density of Dunaliella salina, Tetraselmis chuii, and Isochrysis galbana (cell. $\mathrm{mL}^{-1}$ ) $\times 10^{4}$.

Table 1. The biomass of microalgae

\begin{tabular}{ccc}
\hline Species & Wet biomass $(\mathrm{g})$ & Dry biomass $(\mathrm{g})$ \\
\hline D. salina & 6.65 & 1.026 \\
T. chuii & 7.97 & 1.23 \\
l. galbana & 22.65 & 3.54 \\
\hline
\end{tabular}

Table 2. The result of crude extract of microalgae with methanol solvent

\begin{tabular}{ccc}
\hline Species & Dry biomass $(\mathrm{g})^{\prime}$ & Extract biomass $(\mathrm{g})$ \\
\hline D. salina & 1.026 & 0.33 \\
T. chuii & 1.230 & 0.43 \\
I. galbana & 3.540 & 1.69 \\
\hline
\end{tabular}

inhibiting the growth of selected bacteria was evaluated in this research to support the efforts for fulfilling the important need for aquaculture purposes. Antibacterial activities of three species of microalgae Dunaliella salina, Tetraselmis chuii, and Isochrysis galbana against two species of bacteria's aquatic pathogens Vibrio harveyi and Pseudomonas fluorescence was carried out using the disk diffusion method. The range of the concentrations, Dunaliella salina were $13.32 \mu \mathrm{g} . \mathrm{g}^{-1}, 1.33 \mu \mathrm{g} . \mathrm{g}^{-1}$, and $0.13 \mu \mathrm{g} . \mathrm{g}^{-1}$; Tetraselmis chuii were $12.61 \mu \mathrm{g} . \mathrm{g}^{-1}, 1.26 \mu \mathrm{g} . \mathrm{g}^{-1}$, and 0.13 нg.g-1; and Isochrysis galbana were $13.26 \mu g . g^{-1}$, $1.33 \mu \mathrm{g} . \mathrm{g}^{-1}$, and $0.13 \mu \mathrm{g} . \mathrm{g}^{-1}$, respectively was conducted for the crude extract from methanol solvent of microalgae. Based on the result, the best concentration will be used for the next purification extracted with another solvent.

Furthermore, the organic polar solvent provided extraction yield, ranging from $0.33 \mathrm{~g}$ for Dunaliella salina, $0.43 \mathrm{~g}$ for Tetraselmis chuii, and $1.69 \mathrm{~g}$ for Isochrysis galbana. It was obtained from 3 $\mathrm{L}$ and $1.5 \mathrm{~L}$ of culture. The crude extract for methanol solvent with high polarity was able to extract the antimicrobial compound. Several authors (Borowitzka, 1995, Ozdemir et al., 2004) have attributed the cyanobacteria antimicrobial activity to different compounds.

\section{Antibacterial activities}

The antibacterial activities were carried out by using disk diffusion methods. The tested bacteria were counted for their density by using the McFarland standards method (Table 3.). The result of antibacterial activity by using the disk diffusion method against Vibrio harveyi is shown in Table 4 and against Pseudomonas fluorescence is shown in Table 5. Antibacterial activity of various extracts of the microalgae Spirulina platensis (Pradhan et al., 2011), Euglena viridis (Das et al., 2005), cyanobacteria (Najdenski et al., 2013), have been reported as the main groups of microalgae to produce antimicrobial substances.

The result of antibacterial activities in this study showed that only Tetraselmis chuii provided the inhibition zone against two tested bacteria $V$. harveyi with the inhibition zone $3.0 \pm 0.6 \mathrm{~mm}$ on $100 \mu \mathrm{g} . \mathrm{g}^{-1}$ of extract concentration and $4.2 \pm 1.1 \mathrm{~mm}$ against $P$. fluorescence on $10000 \mu \mathrm{g} . \mathrm{g}^{-1}$ of extract concentration. The result is similar to the finding that methanol extracts of Tetraselmis sp. showed maximum zone of inhibition against Pseudomonas $\mathrm{sp}$ (Rajendran et al., 2014). Furthermore, Kokou et al (2012) found that Tetraselmis chuii and Isochrysis sp showed antibacterial activity against six (6) Vibrio bacterial strains: V. parahaemolyticus, V. anguillarum,

Table 3. Results of McFarland standard for bacteria

\begin{tabular}{lll}
\hline Bacteria & OD & $\begin{array}{l}\text { Cell density (cell. } \\
\mathrm{mL}-1)\end{array}$ \\
\hline $\begin{array}{l}\text { Vibrio harveyi } \\
\begin{array}{l}\text { Pseudomonas } \\
\text { fluorescence }\end{array}\end{array}$ & 0.671 & $12 \times 10^{8}$ \\
\hline
\end{tabular}

Note : OD: Optical Density 
ILMU KELAUTAN: Indonesian Journal of Marine Sciences December 2021 Vol 26(4):265-270

Table 4. Antibacterial activity of microalgae against Vibrio harveyi

\begin{tabular}{|c|c|c|c|c|c|c|}
\hline \multirow{3}{*}{ Species } & \multicolumn{6}{|c|}{ Inhibition zone (mm) } \\
\hline & \multicolumn{3}{|c|}{$24 \mathrm{~h}$} & \multicolumn{3}{|c|}{$48 \mathrm{~h}$} \\
\hline & $\left.a^{*}\right)$ & $\left.\mathrm{b}^{*}\right)$ & $\left.C^{*}\right)$ & $\left.a^{*}\right)$ & $\left.b^{*}\right)$ & $\left.C^{*}\right)$ \\
\hline Dunaliella salina & $4.4 \pm 0.6$ & $1.8 \pm 0.4$ & 0 & $4.3 \pm 0.9$ & $1.8 \pm 0.3$ & 0 \\
\hline Tetraselmis chuii & $3.5 \pm 0.7$ & $2.3 \pm 0.3$ & $3.0 \pm 0.6$ & $3.5 \pm 0.7$ & $2.2 \pm 0.3$ & $2.9 \pm 0.5$ \\
\hline Isochrysis galbana & $3.2 \pm 0.7$ & $2.9 \pm 0.2$ & $2.5 \pm 0.8$ & $3.0 \pm 0.6$ & $2.9 \pm 0.2$ & $2.5 \pm 0.7$ \\
\hline
\end{tabular}

Note: The concentration of $V$ harveyi for a: $10000 \mu g$. g-1; b: $1000 \mu g . g^{-1}$; c: $100 \mu g . g^{-1}$; *) Mean \pm SD

Table 5. Antibacterial activity of microalgae against Pseudomonas fluorescence.

\begin{tabular}{|c|c|c|c|c|c|c|}
\hline \multirow{3}{*}{ Species } & \multicolumn{6}{|c|}{ Inhibition zone (mm) } \\
\hline & \multicolumn{3}{|c|}{$24 \mathrm{~h}$} & \multicolumn{3}{|c|}{$48 \mathrm{~h}$} \\
\hline & $\left.a^{*}\right)$ & $\left.\mathrm{b}^{\star}\right)$ & $\left.C^{*}\right)$ & $\left.a^{*}\right)$ & $b^{*}$ & $\left.C^{*}\right)$ \\
\hline Dunaliella salina & 0.0 & 0.0 & 0.0 & 0.0 & 0.0 & 0.0 \\
\hline Tetraselmis chuii*) & $4.2 \pm 1.1$ & $3.2 \pm 0.5$ & $3.1 \pm 0.1$ & $4.2 \pm 0.9$ & $2.9 \pm 0.2$ & $3.1 \pm 0.2$ \\
\hline Isochrysis galbana & 0.0 & 0.0 & 0.0 & 0.0 & 0.0 & 0.0 \\
\hline
\end{tabular}

Note: The concentration of $P$. fluorescence for a: $10000 \mu g . g^{-1}$; b: $1000 \mu g . g^{-1} ;$ c: $100 \mu g . g^{-1}$; *) Mean \pm SD

V. splendidus, V. scophthalmi, V. alginolyticus, and V. lentus. Besides antibacterial activity, Tetraselmis chuii is an important producer of fatty acid, and this is an insignificant relationship with environmental conditions (Mohammadi et al., 2015).

Meanwhile, two microalgae, Dunaliella salina and Isochrysis galbana tested, have the inhibition zone only against $V$. harveyi with the inhibition zone $4.4 \pm 0.6 \mathrm{~mm}$ and $3.2 \pm 0.7 \mathrm{~mm}$ on $10000 \mu \mathrm{g}$. $\mathrm{g}^{-1}$ of extract concentration. This result is in agreement with the finding of Molina-Cárdenas et.al (2014) that demonstrate Isochrysis galbana synthesizes antibacterial fatty acids that inhibit the growth of pathogenic bacteria such as $V$. harveyi, $V$. alginolyticus, and V. campbellii.

The antimicrobial compounds of microalgae are expected due to their lipids contains. Lipids and some free fatty acids are known to show antibacterial activities from algae (Desbois and Smith, 2010; Plaza et al., 2010). It has been shown that the promoting effect on membrane damage leads to a leakage of molecules from the microbial cells, reduction in nutrient uptake, or inhibition of cellular respiration (Smith et al., 2010). An antibiotically active fatty acid is presented in a high concentration in algae as stated by Hoai Thu et al. (2015), found that I. galbana Parke, strain HP has the highest content of Docosahexaenoic acid (DHA), up to $14.7 \%$ of total fatty acid and maximal Polyunsaturated fatty acids (PUFAs) values at the early stationary phase. The primary PUFAs are stearidonic acid (18:4n-3) (Nalder et al., 2015).

\section{Conclusion}

The crude extract of three species microalgae, Dunaliella salina, Tetraselmis chuii, and
Isochrysis galbana, can be used as antibacterial activity against aquatic pathogens Vibrio harveyi and Pseudomonas fluorescence. The best result for the aquatic purpose was $T$. chuii which can inhibit both pathogenic bacteria $V$. harveyi and $P$. fluorescence and also have antibacterial activities for three replicas. Hence, it is necessary to carry out further research about the availability of microalgae resources as a new functional feed for aquaculture.

\section{Acknowledgments}

The authors would like to thank the Indonesian Ministry of Research, Technology and Higher Education, for funding this research by the Implementation Agreement Assignment Research Collaboration and International Publication No.34336/UN7.5.1/PP/2017, and also thank Ragil Susilowati and Robertus Triaji Mahendrajaya for helping the culture of microalgae in the laboratory.

\section{References}

Borovkov, A.B., Gudvilovich, I.N., Memetshaeva, O.A., Avsiyan, A.L., Lelekov, A.S. \& Novikova, T.M. 2019. Morphological and Morphometrical Features in Dunaliella salina (Chlamydomonadales, Dunaliellaceae) During the Two-phase Cultivation Mode. Ecol. Montenegrina 22: 157165. doi: 10.37828/em. 2019.22.12

Borowitzka, M.A. 2021. The Mass Culture of Dunaliella salina. https://www.fao.org/3/ab7 28e/ab728e06.html. Online access: October 26, 2021.

Borowitzka, M.A. 1995. Microalgae as source of pharmaceuticals and biologically active compounds. J. Appl. Phycol. 7: 3-15. doi: 10.1007/BF00003544. 
Cordoba-Matson, M.V., Arredondo-Vega, B.O. \& Carreon-Palau, L. 2013. Evaluation of growth, cell size and biomass of Isochrysis aff. galbana (T-ISO) with two LED regimes. All Res. J. Biol. 4: 7-15.

Das, B.K., Pradhan, J., Pattnaik, K., Samantray, B.R. \& Samal, S.K. 2005. Production of antibacterials from the freshwater alga Euglena viridis (Ehren). World. J. Microbiol. Biotechnol. 21: 45-50. doi: 10.1007/s11274-004-1555-3.

Desbois, A. P \& Smith, V.J. 2010. Antibacterial free fatty acids: activities, mechanisms of action and biotechnological potential. Appl. Microbiol. Biotechnol. 85: 1629-1642. doi: 10.1007/s00 253-009-2355-3.

Hadioetomo, R.S. 1993. Mikrobiologi Dasar dalam Praktek: Teknik dan Prosedur Dasar Laboratorium. PT Gramedia Pustaka Utama. Jakarta. 163 hal.

Hardouin, K., Burlot, A.S., Umami, A., Tanniou, A., Stiger-Pouvreau, V., Widowati, I., Bedoux, G. \& Bourgougnon, N. 2013. Biochemical and antiviral activities of enzymatic hydrolysates from different invasive French seaweeds. J. Appl. Phycol. 26: 1029-1042. doi: 10.1007/ s10811-013-0201-6.

Harrison, P.J \& Berges, J.A. 2005. Marine Culture Media. In. Algal Culturing Techniques. $(E d)$ R.A. Andersen. $1^{\text {st }}$ Ed. Burlington: Elsevier Academic Press. $578 p$.

Hoai Thu, N.T., Lan Anh, H.T., Hien Hoang, M., Kim, D.D. \& Hong, D.D. 2015. Study on Biological Characteristics of a Newly Isolated Vietnamese Strain of Microalga Isochrysis galbana Parke for Utilizing as Live Aquaculture Feed. Russian. J. Mar. Biol. 41 (3): 203-211. doi: 10.1134/S10 63074015030074.

Khatoon, H., Abdu Rahman, N., Banerjee, S., Harun, N., Suleiman, S.S., Nur Zakaria, N.H., Lananan, F., Abdul, S.H., Hamid \& Endut, A. 2014. Effects of different salinities and $\mathrm{pH}$ on the growth and proximate composition of Nannochloropsis sp. and Tetraselmis sp. isolated from South China Sea cultured under control and natural condition. Int. Biodet. Biodeg., 95: 11-18. doi: 10.1016/j.ibiod.2014.06.022.

Kokou, F., Makridis, P., Kentouri, M. \& Divanach, P. 2012. Antibacterial activity in microalgae cultures. Aquacul. Res., 43: 1520-1527. doi: 10.doi1111/j.1365-2109.2011.02955.x.
Lavens, P. \& Sorgeloos, P. 1996. Manual on the production and use of live food for aquaculture. Rome: FAO Fisheries Technical Paper.

Mishra, S.K., Shrivastav, A., Maurya, R.R., Patidar, S.K., Haldar, S. \& Mishra, S. 2012. Effect of light quality on the C-phycoerythrin production in marine cyanobacteria Pseudanabaena sp. isolated from Gujarat coast, India. Protein. Expr. Purif. 80: 234-238. doi: 10.1016/j.pep.2011. 08.011.

Mohammadi, M., Kazeroni, N. \& Baboli, M.J. 2015. Fatty acid composition of the marine microalga Tetraselmis chuii Butcher in response to culture conditions. J. Algal. Biomass. Utın. 6 (2): 49- 55.

Molina-Cárdenas, C.A., del P. Sánchez-Saavedra, M \& Lizárraga-Partida, M.L. 2014. Inhibition of pathogenic Vibrio by the microalgae Isochrysis galbana. J. Appl. Phycol. 26: 2347-2355. doi: 10.1007/s10811-014-0270-1.

Najdenski, H.M., Gigova, L.G., Iliev, I.I., Pilarski, P.S., Lukavsky, J., Tsvetkova, I.V., Ninova, M.S. \& Kussovski, V.K. 2013. Antibacterial and antifungal activities of selected microalgae and cyanobacteria. Int. J. Food. Sci. Technol. 48: 1533-1540. doi: 10.1111/ijfs.12122.

Nalder, T.D., Miller, M.R. \& Packer, M.A. 2015. Changes in lipid class content and composition of Isochrysis sp. (T-Iso) grown in batch culture. Aquacult Int. 23(5): 1293-1312. doi: 10.1007/ s10499-015-9884-9.

Ozdemir, G., Karabay, N.U., Dalay, M.C. \& Pazarbasi, B. 2004. Antibacterial activity of volatile component and various extracts of Spirulina platensis. Phytother. Res., 18: 754-757. doi: 10.1002/ptr.1541.

Plaza, M., Santoyo, S., Jaime, L., García-Blairsy, R.G., Herrero, M., Señoráns, F.J. \& Ibáñez, E. 2010. Screening for bioactive compounds from algae. J. Pharm. Biomed. Anal. 51(2): 450-455. doi: 10.1016/j.jpba.2009.03.016.

Pradhan, J., Das, P.K., Sahu, S., Marhual, N.P., Swain, A.K., Mishra, B.K. \& Eknath, A.E. 2011. Traditional antibacterial activity of freshwater microalgae Spirulina platensis to aquatic pathogens. Aquacul. Res. 43: 1287-1295.

Rajendran, N., Selvan, B.K., Piriya, P.S., Logeswari, V., Kathiresan, E., Tamilselvi. A. \& John Vennison, S.J. 2014. Phytochemicals, Antimicrobial and Antioxidant Screening From Five Different 
Marine Microalgae. J. Chem. Pharm. Sci. 7(2): 78-85.

Radjasa, O. K., Limantara, L. \& Sabdono, A. 2009. Antibacterial activity of a pigment producingbacterium associated with Halimeda sp. from Land-Locked marine Lake Kakaban, Indonesia. J. Coast. Dev. 12 (2): 100-104

Smith, V. J., Desbois, A.P. \& Dyrynda, E.A. 2010. Conventional and unconventional antimicrobials from fish, marine invertebrates and microalgae. Marine Drugs. 8: 1213-1262. doi:10.3390/ md8041213.

Susilowati, R., Sabdono, A. \& Widowati, I. 2015. Isolation and characterization of bacteria associated with brown algae Sargassum spp. from Panjang island and their antibacterial activities. Procedia. Env. Sci. 23: 240-246. doi: 10.1016/j.proenv.2015.01.036.
Trianto, A., Hermawan, I., Suzuka, T. \& Tanaka, J. 2011. Two new cytotoxic Candida spongiolides from an Indonesian Sponge. ISRN Pharm., 852619. doi: 10.5402/2011/852619.

Widowati, I., Daphné, L., Puspita, M. \& Bourgougnon, N. 2014. Antibacterial and Antioxidant Properties of the Red Alga Gracillaria verrucosa from the North Coast, Java, Semarang, Indonesia. Int. J. Latest Res. Sci. Technol., 3(3): 179-185

Widowati, I., Zainuri, M., Kusumaningrum, H.P., Susilowati, R., Hardivillier, Y., Leignel, V., Bourgougnon N. \& Mouget, J.L. 2017. Antioxidant activity of three microalgae Dunaliella salina, Tetraselmis chuii and Isochrysis galbana clone Tahiti. IOP Conference Series: Earth and Environmental Science 55: 012067, doi: 10.1088/1755-1315/55/1/01 2067. 